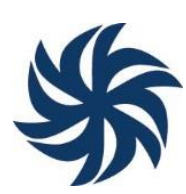

\title{
ESTUDO EXPLORATÓRIO SOBRE O EFEITO DO FIM DAS COLIGAÇÕES NAS ELEIÇÕES MUNICIPAIS BRASILEIRAS DE 2020
}

\author{
EXPLORATORY STUDY ABOUT THE EFFECT OF THE EXCLUSION OF \\ COALITIONS IN 2020 BRAZILIAN MUNICIPAL ELECTIONS
}

\author{
ESTUDIO EXPLOTATORIO SOBRE EL EFECTO DE LA AUSENCIA DE \\ COALICIONES EN LAS ELECCIONES MUNICIPALES BRASILEÑAS DE 2020
}

Thiago Alexandre Melo Matheus ${ }^{1}$

\begin{abstract}
Resumo: Diversos estudos já discutiram as consequências que as coligações teriam para a fragmentação partidária e para a representatividade das candidaturas em eleições proporcionais no Brasil. O presente trabalho pretende resgatar essas discussões e analisar a dinâmica entre coligações e resultados eleitorais no contexto das eleições municipais de 2020. Esse estudo exploratório é realizado a partir de comparações entre os dados de 2016 e 2020, tentando identificar possíveis consequências que o fim das coligações nas eleições proporcionais pode ter provocado nos resultados dos pleitos municipais e a partir disso refletir sobre possíveis impactos nas eleições de 2022. As análises realizadas sugerem influência do fim das coligações no grau de fragmentação das bancadas municipais e também nas estratégias eleitorais dos partidos. Espera-se que os resultados alcançados possam contribuir para entender as dinâmicas que surgiram no sistema político brasileiro com o fim das coligações e também sugerir caminhos para pesquisas futuras.
\end{abstract}

Palavras-chave: Coligações Partidárias; Sistemas Eleitorais; Sistemas Partidários; Eleições Municipais.

Abstract: Several studies have already discussed the consequences that coalitions have for party fragmentation and representativity in Brazilian proportional elections. The present work intends to present these discussions and analyze the dynamics between coalitions and electoral results in the context of the 2020 Brazilian municipal elections. This exploratory study is based in comparisons between the data of 2016 and 2020 elections and tries to identify possible consequences that the end of the coalitions in the proportional elections may have provoked in the results of the municipal elections. From there, possible impacts in the national elections of 2022 are discussed. The analyzes suggest the influence of the end of the coalitions on the degree of fragmentation of the municipal benches and also on the electoral strategies of the parties. It is hoped that the results achieved will contribute to those who seek to understand the dynamics that arose in the Brazilian political system with the end of coalitions and also suggest paths for future research.

Keywords: Party Coalitions; Municipal Elections; Electoral Systems; Party Systems.

Resumen: Varios estudios ya han discutido las consecuencias que tendrían las coaliciones para la fragmentación y la representatividad de los partidos en las elecciones proporcionales brasileñas. El presente trabajo pretende presentar estas discusiones y analizar la dinámica entre coaliciones y resultados electorales en el contexto de las elecciones municipales brasileñas de 2020. Este estudio exploratorio se basa en comparaciones entre los datos de las elecciones municipales de 2016 y 2020 e intenta identificar las posibles consecuencias que el fin de las coaliciones en las elecciones proporcionales pudo haber provocado en los resultados de 2020. Los análisis sugieren la influencia del fin de las coaliciones sobre el grado de

\footnotetext{
1 Aluno do Mestrado Profissional em Poder Legislativo do Centro de Formação da Câmara dos Deputados (CEFOR). E-mail: thiagoamm@gmail.com
} 
fragmentación de los escaños municipales y también sobre las estrategias electorales de los partidos. Entonces, a partir de los resultados alcanzados pretenden contribuir a quienes buscan comprender la dinámica que surgió en el sistema político brasileño con el fin de las coaliciones y también sugerir caminos para futuras investigaciones.

Palabras clave: Coaliciones de partidos; Sistemas electorales; Sistemas de partidos; Elecciones municipales.

\section{Introdução}

Diversos estudos já discutiram as consequências que das coligações para a fragmentação partidária e para a capacidade representativa das candidaturas em eleições proporcionais. O efeito das coligações no sistema político brasileiro é estudado por teóricos da Ciência Política desde a década de 1960 (SOARES, 1964), mas foi apenas nos últimos 30 anos que o tema se tornou mais presente nos debates legislativos sobre reforma eleitoral culminando em 2017 com a promulgação da Emenda Constitucional 97/2017 (BRASIL, 2017). Essa alteração retirou a possibilidade de realização de coligações para a eleição de membros dos legislativos municipais, estaduais e federal. Porém, foi estabelecido que essa regra valeria apenas a partir do pleito municipal de 2020.

Daí surge a grande importância de se estudar os resultados dessa eleição, pois ela se tornou uma espécie de balão de ensaio em que podem ser analisadas as possíveis consequências do fim das coligações para os resultados eleitorais e nas estratégias partidárias. Dessa forma, o presente trabalho realiza um estudo exploratório baseado em comparações dos dados das eleições municiais de 2016 e 2020, com intuito de analisar efeitos decorrentes do fim das coligações nas eleições proporcionais e sua influência nos resultados. A partir disso, busca-se explorar como esses efeitos podem impactar as eleições de 2022.

O presente trabalho foi estruturado a partir de uma breve revisão bibliográfica, que inclui um apanhado histórico sobre o estudo das coligações no sistema eleitoral brasileiro, e de uma pesquisa sobre as proposições legislativas apresentadas na Câmara dos Deputados que tinham como objetivo o fim das coligações, analisando as justificativas que os parlamentares apresentavam sobre quais consequências a alteração pretendida poderia provocar no sistema político brasileiro, em particular, na dinâmica das eleições proporcionais. Na sequência é apresentada a discussão sobre os resultados obtidos, contextualizando os dados das eleições de 2020 com as discussões presentes na bibliografia previamente apresentada. Na conclusão buscase ressaltar os achados mais relevantes relacionados à nova dinâmica eleitoral que surgiu no sistema político brasileiro em decorrência do fim das coligações e são sugeridos alguns temas interessantes para próximas pesquisas.

\section{Breve histórico das coligações no Sistema Eleitoral Brasileiro}

Em 4 de outubro de 2017 foi promulgada a Emenda Constitucional 97/2017 (BRASIL, 
1997) $)^{2}$, que extinguiu a possibilidade de os partidos realizarem coligações nas eleições proporcionais. Esse instituto surgiu pela primeira vez no Direito brasileiro 85 anos antes, com o nome de "aliança de partidos" 3". Tal novidade trazida pelo Código Eleitoral de 1932, rebatizada posteriormente como coligação partidária, foi utilizada desde então com exceção de eleições ocorridas durante os períodos do Estado Novo e do Regime Militar (1964 - 1985).

Segundo Miranda (2013), os debates sobre a consequência das coligações na eleição de membros do legislativo ganharam força na década de 60, quando surgiram estudos como os de Gláucio Ary Dillon Soares que tentavam analisar seus impactos nas estratégias eleitorais dos partidos e seus efeitos nos resultados das eleições. Os estudos de Soares (1964) tinham como objetivo analisar a natureza das coligações, até então chamadas de alianças, realizadas nas eleições proporcionais entre 1950 e 1962. Para esse autor, o comportamento coligacionista orientava-se por duas racionalidades: o esforço mínimo e a resistência ideológica.

A tese do esforço mínimo, ou economia de esforços, seria decorrente das alianças firmadas pelos partidos com intuito de maximizar os ganhos eleitorais. Soares (1964) apresentou em sua pesquisa três hipóteses a respeito da tese do esforço mínimo: a) os pequenos partidos são mais propícios à formação de alianças para facilitar que alcancem o quociente eleitoral; b) quanto maior o quociente eleitoral maior será o número de alianças; e c) alianças são mais frequentes nas eleições majoritárias do que nas proporcionais.

Já a tese da resistência ideológica, segundo o autor, se manifestaria quando o partido, visando alcançar o quociente eleitoral, realizava o cálculo das perdas e ganhos decorrentes de alianças com partidos de diferentes correntes ideológicas. Soares (1964) acreditava que nas pequenas cidades os partidos tendiam a ser menos ideológicos que nos maiores centros urbanos, fator que facilitaria a realização de coligações. Além disso, partidos com ideologia mais enraizada e com base social mais determinada estariam também menos propensos a realizar alianças.

Conforme Carreirão (2006), nas décadas seguintes além das discussões sobre as estratégias eleitorais relacionadas à realização de coligações, se intensificaram os estudos que abordavam seus possíveis impactos na estrutura do sistema político brasileiro, especialmente nas suas consequências para a representação na Câmara Federal. Com destaque para os trabalhos de Souza (1976), Nicolau (1996) e Tavares (1998), entre outros.

Porém, além do debate teórico, a discussão sobre a aplicação do instituto das coligações nas eleições proporcionais passou a ser tema recorrente também da pauta das reformas políticas

\footnotetext{
2 A Emenda Constitucional 97/2017 decorrente da PEC 36/2016 apresentada no Senado Federal pelo senador Ricardo Ferraço (PSDB/ES) depois de aprovada foi enviada à Câmara dos Deputados sendo renumerada para PEC 282/2016. Após aprovação com alterações na Câmara dos Deputados voltou para o Senado Federal sendo renumerada como PEC 33/2017 sendo por fim aprovada sem alterações e promulgada pelo Congresso Nacional.

${ }^{3}$ Decreto no 21.076, de 24 de fevereiro de 1932 (Código Eleitoral). Art. 58. Processa-se a representação proporcional nos termos seguintes.

$1^{\circ}$ É permitido a qualquer partido, aliança de partidos, ou grupo de cem eleitores, no mínimo, registrar, no Tribunal Regional, até cinco dias antes da eleição, a lista de seus candidatos, encimada por uma legenda.
} 
no Congresso Nacional. Sua eventual relação com a eleição de deputados de pequenos partidos, que sozinhos não alcançariam o quociente eleitoral, e a consequente fragmentação partidária ocorrida nas casas legislativas no decorrer da década de 90 ocasionaram uma enxurrada de propostas de alteração do Código Eleitoral, visando à proibição das coligações. Essa movimentação dos congressistas se intensificou após o ano de 1999, com a apresentação na Câmara dos Deputados do Projeto de Lei 668/1999 pelo então deputado Aloysio Nunes Ferreira (PSDB/SP). Cabe destacar partes da argumentação constantes na justificação do projeto:

Em resumo, o expediente das coligações tem desvirtuado o sistema proporcional no que ele tem de mais característico: o partido deixa de ser a referência principal do resultado eleitoral, podendo o eleitor votar em um partido e eleger candidato de outro. Com isto, as representações dos partidos políticos na Câmara dos Deputados e nas demais Casas preenchidas por eleições proporcionais não correspondem efetivamente à força eleitoral das agremiações partidárias.

A proibição de coligações em pleitos proporcionais tem sido muitas vezes incluída na pauta da reforma política como parte da discussão sobre as vantagens e desvantagens da participação de partidos pouco votados nos órgãos de representação. Ou seja, supõe-se que o fim das coligações seja defendido apenas pelos que consideram que um número menor de partidos políticos nas Casas legislativas teria consequências benéficas para os processos decisórios. Tal percepção é equivocada.

As coligações podem efetivamente facilitar a subsistência de partidos menos votados, mas não é exatamente por isto que devemos excluí-las do ordenamento jurídico. Devemos fazê-lo, de fato, porque distorcem a representação, permitindo que partidos sem votos suficientes para eleger representantes ocupem cadeiras nas casas legislativas pela via da coligação. (BRASIL, 1999, p. 132).

Apesar de mencionar que a eliminação das coligações nas eleições proporcionais poderia diminuir o número de partidos eleitos para a Câmara dos Deputados, o autor do projeto ainda não defendia explicitamente a existência de relação direta das coligações com a fragmentação partidária, que na época aumentava significativamente nas casas legislativas (PAIVA; ALVES; BENEDITO, 2013). O principal ponto do senador Sérgio Machado era o desvirtuamento do princípio da proporcionalidade das eleições em decorrência das coligações que era responsável pelos partidos não obterem um número de cadeiras proporcional à sua votação ${ }^{4}$ e possibilitava que o voto dado a um partido resultasse na eleição de um candidato de outra legenda. Mais frequentemente representantes de pequenos partidos.

Podem ser relacionados diversos projetos de lei que foram posteriormente apresentados com a mesma ideia do PLS 178/1999. Alguns exemplos são o PL 1336/1999 do deputado José Antônio Almeida (PSB/MA), PL 3367/2000 do deputado Ricardo Ferraço (PSDB/ES), PL 82/2003 do deputado Roberto Magalhães (PSDB/PE), PL 7048/2002 do deputado Coriolano Sales

\footnotetext{
${ }^{4}$ Apesar de se saber que o fim das coligações nas eleições não representaria uma proporcionalidade absoluta em virtude da existência do quociente eleitoral e do Método D’Hondt para o cálculo das sobras.
} 
(PMDB/BA), PL 551/2003 do deputado José Roberto Arruda (PFL/DF) e PL 1067/2003 do deputado Pompeo de Mattos (PDT/RS). Percebe-se, nessa lista deputados de diferentes partidos, perfis ideológicos e unidades da federação. Tal convergência de pensamento entre os parlamentares proporcionou que no início da 52. ${ }^{a}$ Legislatura a Comissão Especial da Câmara dos Deputados destinada a efetuar estudo em relação à Reforma Política apresentasse o Projeto de Lei 2679/2003 que em seu conteúdo trazia a proposta do fim das coligações para eleição de parlamentares. Na justificação desse projeto essa comissão de estudos da Câmara dos Deputados destacava de forma clara e objetiva a possível relação da aplicação das coligações nas eleições proporcionais e a crescente fragmentação partidária nas casas legislativas. Cabe citar o seguinte trecho da justificação da proposta:

A mecânica mencionada é habitualmente ignorada pelo eleitor, que sufraga um candidato, sem saber que o voto que a ele confere pode, na verdade, vir a eleger candidato de outro partido. Não raro, um candidato da agremiação maior na coligação deixa de ser eleito, porque vem a ser preterido pelo da agremiação menor. Esta, sem a coligação, não teria alcançado o quociente.

A prática dilui as diferenças entre os partidos, parecendo servir apenas de expediente para burlar a barreira legal. Além disso, a não permanência da coligação após o pleito, no trabalho legislativo, acentua o caráter oportunista e episódico da aliança. (...)

Não menos significativo em nossa vida política tem sido o problema da fragmentação do quadro partidário, já implicitamente mencionado quando falamos do tema das coligações nas eleições proporcionais. Diagnósticos de faz alguns anos viam como extremamente negativa a proliferação de legendas, propiciada por normas legais demasiado permissivas para a criação de partidos. (BRASIL, 2003, p. $15)$.

Mesmo não obtendo êxito na reforma política de 2003, a discussão sobre o fim das coligações nas eleições proporcionais não arrefeceu e se tornou recorrente em várias das tentativas subsequentes de reforma política - incluindo as que aconteceram em 2007, 2012 e 2015 - até a ideia obter sucesso 14 anos depois por meio da Emenda Constitucional 97/2017. Apesar de sua promulgação em 2017, a emenda constitucional estabelecia que somente a partir das eleições municipais de 2020 as coligações estariam extintas. Desta forma, embora a maioria dos estudos sobre o efeito das coligações foque em suas consequências para a Câmara dos Deputados ou Assembleias Legislativas, as eleições municipais de 2020 ganharam enorme relevância por servirem de laboratório para análises reais sobre os impactos que o fim das coligações pode realmente causar na representação dos partidos nas casas legislativas. Os resultados eleitorais das câmaras dos vereadores das principais capitais, em particular, guardam grande similaridade com o esperado para as eleições nacionais.

\section{Consequências esperadas com o fim das coligações nas eleições proporcionais}

Antes de imergir na análise dos dados das eleições de 2020 é interessante apresentar algumas discussões de cientistas políticos e também opiniões de congressistas sobre quais seriam 
as consequências nas eleições para o Legislativo e suas possíveis implicações para o sistema político brasileiro se as coligações fossem extintas.

Para Nicolau (1996), a previsão da existência das coligações em eleições proporcionais tinha como principal função possibilitar que os pequenos partidos não tivessem a obrigação de individualmente terem que alcançar um alto quociente eleitoral. Segundo o autor, o sistema eleitoral brasileiro apresentava em seu funcionamento um certo grau de desproporcionalidade que tinha como característica a tendência de beneficiar os grandes partidos, gerando o que a literatura conhece como "efeito mecânico de Duverger". Assim, a realização de coligações seria uma forma das pequenas siglas minimizarem esse fenômeno. No entanto, sua influência foi determinante para o crescimento da fragmentação no plano nacional, principalmente na composição da Câmara dos Deputados, segundo Jairo Nicolau (1996).

Já de acordo com Albuquerque (2017), existiriam duas consequências provocadas pelas coligações no sistema eleitoral brasileiro:

Em primeiro lugar, não são os partidos coligados que precisam ultrapassar o quociente eleitoral para aspirarem às vagas em disputa, mas sim as coligações. Isso permite que partidos pequenos - que se competissem sozinhos seriam limados da disputa - consigam efetivamente concorrer a uma das vagas. Essa disposição deturpa o viés majoritário da corrida eleitoral. Partidos que concorrem sozinhos e não alcançam o quociente eleitoral não conquistam nenhuma vaga; partidos coligados que também não alcançam o quociente eleitoral podem acabar conquistando cadeiras.

A segunda consequência reflete na estratégia de lançamento de candidaturas pelos partidos. Eles não precisam ter uma grande proporção de votos em relação ao resto da coligação para que tenham um candidato eleito, mas apenas posicionar seus candidatos entre os mais votados da lista partidária. Para isso, o partido pode concentrar seus votos em um ou dois aspirantes a uma vaga, contando que outros partidos façam o "trabalho sujo" de aumentar a quantidade de votos da coligação. (ALBUQUERQUE, 2017, p. 80).

Segundo Braga (2006), a necessidade de alcançar o quociente eleitoral no sistema brasileiro funcionava como cláusula de exclusão nas eleições visto que a maioria dos partidos não tem força eleitoral distribuída uniformemente no território nacional. Assim a realização de coligações seria uma alternativa para que esses partidos fossem competitivos. Para a autora, com a eliminação das coligações nas eleições proporcionais e manutenção da fórmula de distribuição de sobras eleitorais apenas para partidos que alcançassem o quociente partidário, os prejuízos aos pequenos partidos seriam enormes. Principalmente porque o possível "desperdício" de uma proporção considerável de votos ainda seria uma afronta ao princípio proporcional que a Constituição Federal consagra. Desta forma, Braga (2006) argumenta que uma alternativa para diminuir as desigualdades trazidas pelo fim das coligações seria a eliminação da exigência de os partidos alcançarem o quociente eleitoral para participar da distribuição das sobras eleitorais. Tal mudança permitiria uma distribuição de cadeiras que representaria mais fielmente a vontade do eleitor e evitaria um aumento da desproporcionalidade sistémica produzida pela nova fórmula 
eleitoral (MELO; SOARES, 2016).

Com conclusões similares às de Braga (2006), cabe destacar o estudo elaborado por Raphael Carvalho Silva, da Consultoria Legislativa da Câmara dos Deputados. Em 2015, a partir de simulações com dados de eleições anteriores, o autor previu diversas consequências que a extinção das coligações poderia provocar, em particular, o possível aumento da desproporcionalidade da composição na Câmara dos Deputados, com o favorecimento dos maiores partidos em detrimento dos partidos médios e pequenos. De acordo com os cálculos apresentados por Silva (2015), o fim das coligações proporcionaria um crescimento médio de $39 \%$ para os partidos grandes, prejudicando os partidos médios (redução média de 15\%) e pequenos (redução média de 41\%), caso houvesse manutenção da regra de distribuição das sobras apenas para partidos que alcançassem o quociente eleitoral. Segundo Silva (2015), parte das distorções representativas seria decorrente de distritos de pequena magnitude em que apenas um partido superasse o quociente eleitoral, obtendo assim todas as vagas disputadas. Por exemplo, pelas simulações, nas eleições de 2014, essa situação ocorreria em sete Estados: Acre, Mato Grosso, Rio Grande do Norte, Roraima, Rondônia, Tocantins e Distrito Federal. Todos eles distritos eleitorais com baixa magnitude.

Comparativamente, Silva (2015) mostra que a proposta de fim das coligações combinada com nova regra de partilha das sobras a todos os partidos, poderia ser considerada mais equilibrada em termos de proporcionalidade, pois o crescimento dos partidos grandes seria menor (crescimento médio de 22,4\%) e a redução da representação dos partidos médios (redução média de $8,3 \%$ ) e pequenos (redução média de $15,9 \%$ ) seria menos gravosa. Com a distribuição das sobras entre os diversos partidos, estaria eliminado o risco de um único partido conquistar todas as vagas em um Estado. Isso porque, mesmo nos casos em que só um partido atinja o quociente eleitoral, todos os demais partidos participariam do processo de alocação das sobras.

Essas ideias reverberaram nas discussões dos deputados sobre a PEC 282/2016 ${ }^{5}$ que tratava do fim das coligações nas eleições proporcionais e aparecem explicitamente no parecer apresentado pelo deputado Betinho Gomes à CCJC da Câmara dos Deputados:

\begin{abstract}
Apenas para fins de registro, uma vez que não é objeto do presente parecer o exame de matérias infraconstitucionais, entendemos conveniente anotar que se efetivada a extinção das coligações nas proporcionais, ter-se-á como consequência lógica dessa medida, para a preservação da proporcionalidade exigida pela Constituição, a revogação da regra contida no Código Eleitoral que exclui da distribuição das cadeiras os partidos que eventualmente não alcancem o quociente eleitoral (CE; art. 109, $\$ 2^{\circ}$ ). (BRASIL, 2017a, p. 4).
\end{abstract}

Tal proposta de alteração do Código Eleitoral que alterava a regras da distribuição das sobras eleitorais foi contemplada pelo projeto de lei 8612/2017 ${ }^{6}$ apresentado pela Comissão

\footnotetext{
${ }^{5}$ Originalmente PEC 36/2016 apresentada no Senado Federal pelo senador Ricardo Ferraço (PSDB/ES).

${ }^{6}$ Após aprovação no Senado Federal como Projeto de Lei da Câmara n 110/2017 virou a Lei 13.488/2017 de
} 
Especial para Análise, Estudo e Formulação de Proposições Relacionadas à Reforma Política que estava funcionando na Câmara dos Deputados paralelamente à Comissão Especial de PEC 282/2016. Dessa forma, a mesma reforma eleitoral que determinou o fim das coligações contemplou também a possibilidade de que todos os partidos participantes das eleições pudessem concorrer às vagas restantes após o cálculo do quociente partidário. Essa foi a alternativa encontrada para tentar minimizar eventuais problemas na distribuição das cadeiras que ocasionassem monopólios de partidos nos distritos.

Com base na bibliografia e análises dos parlamentares apresentadas anteriormente podese sintetizar as seguintes consequências esperadas com o fim das coligações nas eleições proporcionais:

- maior sucesso eleitoral para os grandes partidos em detrimento dos médios e pequenos;

- redução da fragmentação partidária nas casas legislativas.

Essas previsões são decorrentes de análises em estudos que focam prioritariamente as consequências que seriam provocadas nas eleições para a Câmara dos Deputados. No entanto, os dados das eleições de 2020 mostraram que a realidade das eleições municipais é diferente daquela das eleições federais tanto pelo comportamento dos eleitores quanto dos partidos. Como Albuquerque (2017) bem destaca, parte da explicação disso se deve federalismo partidário. Enquanto os partidos grandes com sua capilaridade alcançam todos estados e boa parte dos municípios, diversos partidos pequenos são importantes apenas em locais específicos, geralmente os maiores centros urbanos. Isso acaba por gerar uma falta de paralelismo entre algumas das previsões apresentadas por boa parte dos estudos, que focam nas eleições federais, e os resultados observados nas eleições municipais. Existe uma lacuna na literatura de estudos sobre o comportamento das coligações nas esferas municipais e suas consequências e esse artigo procura ajudar a saná-las com as análises a seguir.

\section{Metodologia}

Todos os dados das eleições municipais de 2016 e 2020 empregados nas análises exploratórias do presente estudo foram obtidos no portal do Tribunal Superior Eleitoral (TSE) na data de 10/12/2020. Em particular, foram utilizadas as seguintes bases: "votacao_candidato_munzona_BRASIL", para dados de 2016 (BRASIL, 2020a), e "quociente_eleitoral_partidario", para 2020 (BRASIL, 2020b). Apesar da tabela "quociente_eleitoral_partidario" da eleição de 2016 trazer de forma resumida a relação de municípios e o número de vagas obtidas por cada coligação, a informação não estava individualizada por partido. Logo foi desenvolvido um método para extrair esses dados da tabela

06/10/2017. 
“votacao_candidato_munzona_2016_BRASIL".

Como os dados de 2020 não estavam completos para todos os municípios, preferiu-se realizar comparações sobre a variação no número de partidos que participaram dos pleitos de 2016 e 2020 e do número de cadeiras nas câmaras municipais por partido eleito utilizando-se de valores médios. Foram realizadas também análises sobre a participação dos partidos nas duas eleições, inclusive contabilizando o número de municípios que cada um apresentou candidatos. Dois indicadores foram criados para auxiliar na interpretação dos dados: o "Índice de Sucesso de Campanhas", que é dado pela razão em cada município do número de partidos que elegeram ao menos um candidato a vereador pelo número de partidos que realizaram campanha; e o "Índice de Sucesso Partidário", que representa a fração de municípios em que os partidos conseguiram eleger candidatos em relação ao total.

Cabe destacar novamente que a data de extração dos dados do site do Tribunal Superior Eleitoral foi 10/12/2020. Essa informação é de extrema importância porque o tribunal atualiza seus dados constantemente devido aos resultados dos processos judiciais relacionados às candidaturas o que pode provocar novas totalizações de votos. Assim, quanto mais próximo das eleições os dados são consultados em seu site, maior será a chance de que sofram alguma revisão que os altere posteriormente. Com base nessa situação, nas análises realizadas neste trabalho foram considerados apenas os municípios que estavam com dados completos disponíveis. Isso pode gerar uma pequena divergência em comparações com estudos futuros que utilizem a mesma base de dados. No momento da extração dos dados - para o ano de 2016 - 99,95\% do total de municípios brasileiros (5.567 municípios) estavam com dados disponíveis. Para 2020 a proporção era um pouco menor, $95,01 \%$ do total (5.292 municípios). Porém, essas pequenas divergências são normais em estudos comparativos e acredita-se que eventuais atualizações nos dados não serão significantes a ponto de provocar mudanças nas conclusões obtidas nesse estudo.

\section{Resultados}

Conforme anteriormente citado é possível resumir as consequências esperadas com o fim das coligações nas eleições proporcionais em dois pontos: maior sucesso eleitoral para os grandes partidos e redução da fragmentação partidária. Os dados das eleições de 2020 agrupados nesse trabalho mostram que a realidade das eleições municipais é diferente daquela das eleições federais, tanto pelo comportamento dos eleitores quanto dos partidos. Assim, apesar dos resultados esperados pelos estudos terem sido alcançados parcialmente, surgiram também questionamentos sobre fenômenos não tão discutidos, como a grande diminuição de partidos disputando as eleições em pequenos distritos e o impacto quase inexistente na fragmentação partidária das câmaras de vereadores das grandes cidades. 


\subsection{Variação do número de partidos disputando as eleições}

Verifica-se pelos dados das eleições de 2020 que, assim como em 2016, quanto maior o número de cadeiras em disputa no município maior foi o número de partidos que lançaram candidatos. Existe um fator que contribui para isso, pois essas cidades maiores geralmente tem uma vida política mais intensa contando com maior número de representações partidárias. Além disso, como leciona Nicolau (1996), em distritos com alta magnitude o efeito mecânico de Duverger é menor, favorecendo as condições de disputa para os pequenos partidos e estimulandoos a participar do pleito. A tabela 1 mostra que em 2020 houve uma redução no número de partidos disputando as eleições, principalmente nos distritos de menor magnitude.

Tabela 1 - Média do número de partidos que participaram das eleições proporcionais em 2016 e 2020 por magnitude ${ }^{7}$ do distrito

\begin{tabular}{cccc} 
& $\mathbf{2 0 1 6}$ & $\mathbf{2 0 2 0}$ & Variação \\
\hline Baixa magnitude & 12,2 & 6,2 & $-45,5 \%$ \\
Média magnitude & 22,0 & 13,6 & $-38,6 \%$ \\
Alta magnitude & 31,5 & 27,4 & $-13,0 \%$ \\
\hline
\end{tabular}

Fonte: Elaboração própria com base em dados do Tribunal Superior Eleitoral, 2020.

Percebe-se que para as três faixas houve redução no número de partidos que participaram das eleições para vereador, sendo essa variação possivelmente influenciada pelo tamanho do distrito. Vale lembrar que quanto menor o distrito, maior é o quociente eleitoral proporcionalmente ${ }^{8}$. E embora atualmente os partidos não precisem mais alcançar o quociente eleitoral para a disputa das vagas das sobras eleitorais, os dados supõem que existe uma força que continua atuando em benefício dos grandes partidos nos menores municípios. Umas das possíveis explicações é que a expectativa dos dirigentes partidários de que ocorreria um aumento do efeito mecânico nas eleições de 2020 pode ter desencorajado o lançamento de candidaturas e consequentemente provocou uma redução no número de partidos nas eleições.

De acordo com Nicolau (1995), essa atitude teria como fundamento o efeito psicológico de Duverger. Segundo o autor, o efeito psicológico, além de influenciar os eleitores, também induz o comportamento dos dirigentes partidários na definição de suas estratégias de campanha eleitoral. Essas decisões seriam tomadas a partir da expectativa de como o efeito mecânico poderia impactar nas oportunidades eleitorais dos partidos. No gráfico seguinte é possível verificar que de forma consistente o número médio de partidos participantes diminuiu independentemente do

\footnotetext{
${ }^{7}$ A magnitude dos distritos foi classificada, de acordo com Dalmoro e Fleischer (2005). Desta forma, são considerados de baixa magnitude os municípios que elegem de 8 a 15 vereadores, de média magnitude os que elegem entre 16 e 24 e de alta magnitude os que elegem mais de 25.

${ }^{8}$ Por exemplo, em um distrito com oito vagas em disputa o quociente eleitoral será de $12,5 \%$ dos votos válidos, já para um distrito com 50 vagas em disputa será de apenas $2 \%$ dos votos.
} 
número de vagas disputadas no município.

Gráfico 1 - Média do número de partidos que participaram das eleições proporcionais em 2016 e 2020 por número de cadeiras do distrito

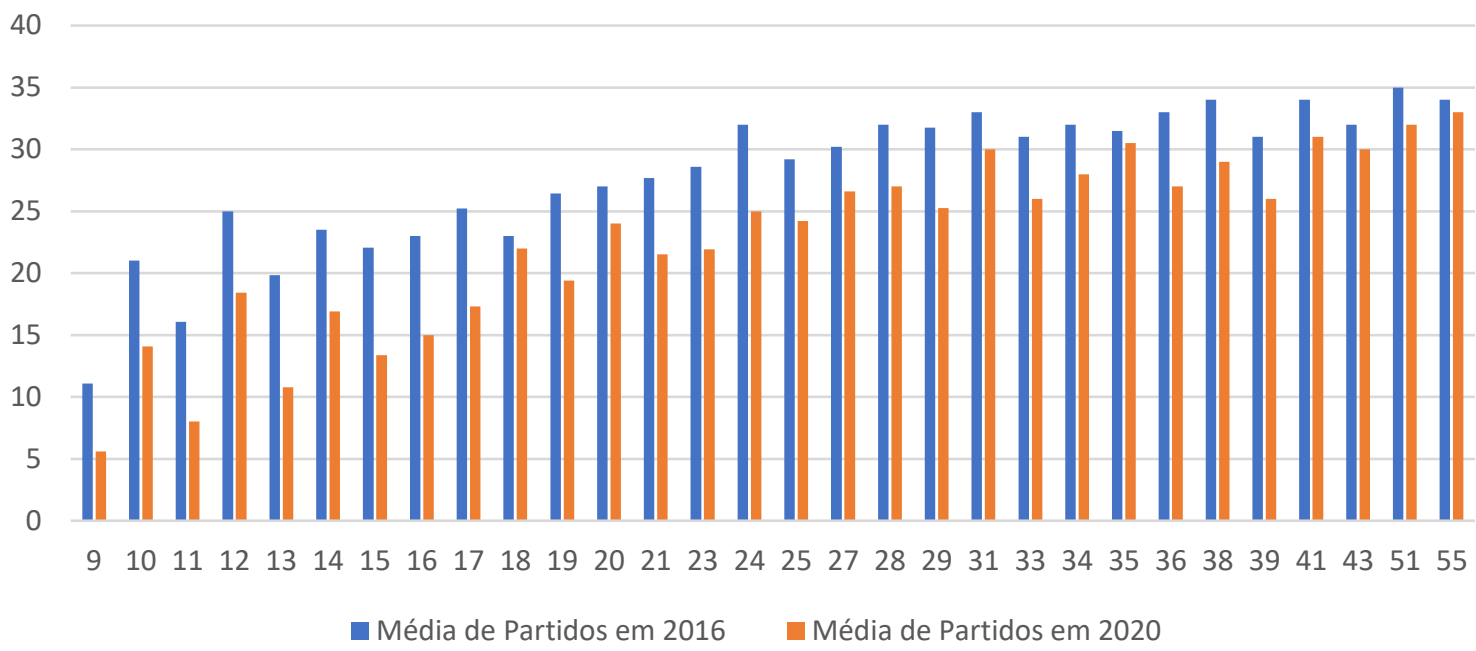

Fonte: Elaboração própria com base em dados do Tribunal Superior Eleitoral, 2020.

O efeito redutor no número de partidos nas eleições com o fim das coligações foi grande nos municípios, mas essa não é uma garantia que acontecerá o mesmo para as eleições estaduais e federais. É importante levar em conta que a capilaridade dos partidos em pequenas cidades pode ter comprometido sua competitividade, fazendo com que eles selecionassem as cidades em que tivessem melhores chances eleitorais. Também é importante destacar possíveis efeitos que a pandemia de Coronavírus pode ter provocado em suas estratégias. Desta forma, provavelmente os melhores parâmetros para o que pode ocorrer em 2022 sejam os resultados fornecidos pelas capitais e municípios de alta magnitude que geralmente tem maior número de representações partidárias e onde a redução média foi bem menor (apenas 13\%). Porém, uma pergunta interessante a ser feita é como essa redução no número de competidores impactou no número de partidos que conseguiram vagas nas Câmaras Municipais. Alguns dados que ajudam a elucidar esses questionamentos serão apresentados a seguir.

\subsection{Variação do número de partidos que elegeram vereadores}

Uma das preocupações dos legisladores ao eliminar a coligação nas eleições proporcionais do ordenamento jurídico brasileiro era reduzir a fragmentação dos partidos nas casas legislativas, porém, sem eliminar as chances de que as pequenas legendas pudessem estar lá representadas. Como vimos anteriormente, os dados das eleições de 2020 nos mostram que houve efetivamente uma redução no número de partidos que participaram das eleições. Mas será que houve também redução entre os que elegeram vereadores? Apesar de algumas distorções que 
serão apresentadas mais a frente, a próxima tabela mostra que os valores médios de número de partidos nas câmaras municipais diminuíram para municípios de baixa, média e alta magnitude.

Tabela 2 - Média do número de partidos que elegeram vereadores em 2016 e 2020 por magnitude do

\begin{tabular}{cccc}
\multicolumn{4}{c}{ distrito } \\
\hline Baixa magnitude & $\mathbf{2 0 1 6}$ & $\mathbf{2 0 2 0}$ & Variação \\
\hline Média magnitude & 6,2 & 4,5 & $-23,5 \%$ \\
Alta magnitude & 9,4 & 8,0 & $-13,8 \%$ \\
& 17,4 & 16,9 & $-2,2 \%$
\end{tabular}

Fonte: Elaboração própria com base em dados do Tribunal Superior Eleitoral, 2020.

De acordo com Nohlen (2006), quanto maior o tamanho do distrito mais fortemente o princípio proporcional se manifestará nele. Em outros termos, mais fraco será o efeito mecânico em suas eleições. Assim, esse fator de maior proporcionalidade da fórmula eleitoral quando aplicada em grandes distritos combinado com a nova regra para distribuição das sobras poderia explicar o fato da média de partidos eleitos para os distritos maiores ter tido uma redução inferior em relação aos de média e baixa magnitude. Além disso, o número de partidos concorrendo nesses distritos foi maior, algo que também contribui para que em termos absolutos o número deles que obteve sucesso fosse maior.

$\mathrm{Na}$ verdade, cabe destacar que, independentemente da magnitude dos distritos, a redução do número de partidos "vencedores" nas eleições de 2020 não acompanhou uma proporção parecida com a de partidos que participaram da eleição.

Tabela 3 - Comparação entre a variação do número médio de partidos que participou das eleições e os que obtiveram sucesso em 2016 e 2020 por magnitude do distrito

\begin{tabular}{|c|c|c|}
\hline & $\begin{array}{c}\text { Variação do número médio de } \\
\text { partidos que participou das eleições }\end{array}$ & $\begin{array}{l}\text { Variação do número médio de } \\
\text { partidos com vereadores eleitos }\end{array}$ \\
\hline Baixa magnitude & $-45,5 \%$ & $-23,5 \%$ \\
\hline Média magnitude & $-38,6 \%$ & $-13,8 \%$ \\
\hline Alta magnitude & $-13,0 \%$ & $-2,2 \%$ \\
\hline
\end{tabular}

Fonte: Elaboração própria com base em dados do Tribunal Superior Eleitoral, 2020.

Ou seja, o efeito do fim das coligações nas eleições proporcionais parece ter provocado maior impacto no número de partidos concorrendo às vagas que no número de partidos que as obtiveram. Como já foi dito, esse não era exatamente o efeito esperado pelos parlamentares com a aprovação da Emenda Constitucional 97/2017. A intenção era a correção das distorções que as coligações provocavam na proporcionalidade da relação votos/vaga, sem inviabilizar a 
participação dos pequenos partidos. Esse ponto pode ser percebido no seguinte trecho do parecer da relatora da matéria no plenário da Câmara dos Deputados, a Deputada Shéridan:

Temos convicção de que o fim das coligações representará um grande avanço em nosso sistema político, pois proporcionará ao eleitor maior compreensão e transparência sobre as consequências de suas escolhas eleitorais e, ao mesmo tempo, garantirá maior governabilidade e estabilidade ao nosso sistema político. Ademais, tomamos todos os cuidados para que o fim das coligações não trouxesse consigo o efeito indesejado de inviabilizar a sobrevivência dos partidos pequenos que representam importantes interesses de minorias e que tanto contribuem para o debate político no Poder Legislativo. (BRASIL, 2017b, p. 7).

A medida mencionada pela relatora foi a inclusão em seu parecer da figura da Federação Partidária ${ }^{9}$, que não prosperou após os debates parlamentares. Apesar disso, percebe-se pela tentativa que havia alguma preocupação por parte dos parlamentares de como o fim das coligações poderia prejudicar a existência das pequenas legendas.

Aparentemente sem a possibilidade de realizar coligações, a estratégia dos partidos foi de concentrar esforços em municípios com maior chance de conquistar vagas. Os dados mostram que obtiveram algum sucesso com isso. Acompanhando a redução no número de competidores, principalmente nos distritos de baixa magnitude, houve um aumento geral no Índice de Sucesso de Campanhas ${ }^{10}$ em 2020. O próximo gráfico apresenta a comparação da média do Índice de Sucesso das Campanhas em 2016 e 2020, agrupados por magnitude do distrito.

Gráfico 2 - Média do Índice de Sucesso das Campanhas em 2016 e 2020 por magnitude do distrito

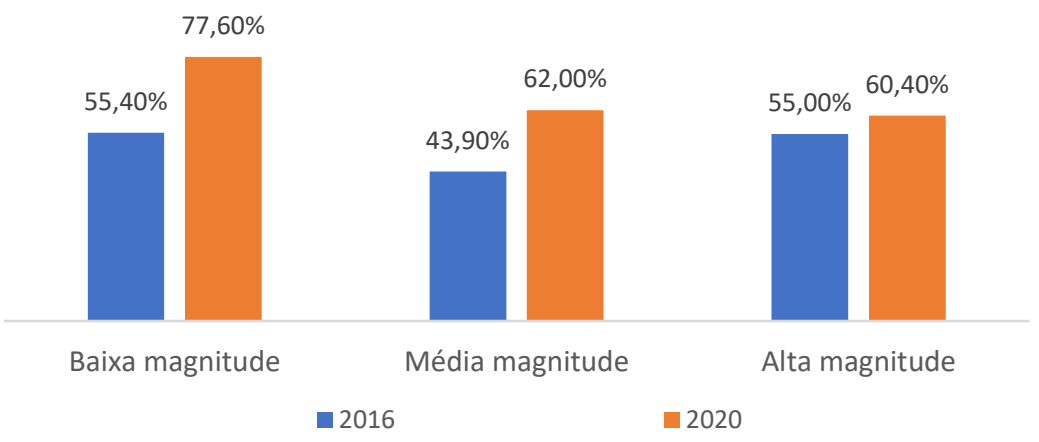

Fonte: Elaboração própria com base em dados do Tribunal Superior Eleitoral, 2020.

No gráfico observa-se que a média do Índice de Sucesso das Campanhas aumentou para todos os tamanhos de distrito. Ou seja, em 2020, entre os partidos que realizaram campanha para

\footnotetext{
${ }^{9}$ As Federações Partidárias seriam uma forma de aliança entre partidos que funcionaria como uma coligação durante o período eleitoral, mas que deveria ser mantida durante toda atuação parlamentar na legislatura seguinte.

${ }^{10} \mathrm{O}$ Índice de Sucesso de Campanhas é dado pela razão, em cada município, do número de partidos que elegeram ao menos um candidato a vereador e o número de partidos que realizaram campanha.
} 
vereador, uma proporção maior conseguir alcançar sucesso elegendo ao menos um candidato quando comparado com 2016. Mas será que o Índice de Sucesso de Campanhas se relaciona com a fragmentação partidária? Sabe-se que podem acontecer casos em que existem vários partidos com bancadas minúsculas nas Câmaras Municipais e um ou dois com grande superioridade numérica. Nesse caso a multiplicidade de partidos talvez não representasse um problema para o funcionamento da casa legislativa. Por isso para ter um melhor parâmetro sobre a fragmentação partidária é importante analisar esse novo cenário de 2020 usando uma ferramenta que dê uma referência também sobre como está a distribuição das vagas entre os partidos, como, por exemplo, o número efetivo de partidos de Laakso e Taagepera (1979).

\subsection{Número efetivo de partidos nas Câmaras Municipais}

Antes de visualizar a situação da fragmentação partidária nas Câmaras Municipais através do número efetivo de partidos, pode-se tentar realizar análises através de um indicador mais simples, como o número médio de cadeiras por partido. A tabela seguinte demonstra que, principalmente nos distritos de menor magnitude, aparentemente ocorreu uma concentração maior de vagas entre os partidos e consequentemente o tamanho médio das bancadas aumentou.

Tabela 4 - Média do número de vagas por partido em 2016 e 2020 por magnitude do distrito

\begin{tabular}{cccc}
\hline & $\mathbf{2 0 1 6}$ & $\mathbf{2 0 2 0}$ & Variação \\
\hline Baixa magnitude & 1,7 & 2,4 & $41,2 \%$ \\
Média magnitude & 1,7 & 2,1 & $23,5 \%$ \\
Alta magnitude & 1,9 & 2,0 & $5,3 \%$ \\
\hline
\end{tabular}

Fonte: Elaboração própria com base em dados do Tribunal Superior Eleitoral, 2020.

Novamente verifica-se que o efeito do fim das coligações, ao influenciar na redução de partidos concorrendo para as câmaras municipais, pode ter gerado consequências mais perceptíveis para distritos de baixa magnitude que tiveram uma redução na concorrência pelas vagas. Esse fenômeno também se manifesta nos valores para o número efetivo de partidos ${ }^{11}$.

Tabela 5 - Média do número efetivo de partidos em 2016 e 2020 por magnitude do distrito

\begin{tabular}{cccc}
\hline & $\mathbf{2 0 1 6}$ & $\mathbf{2 0 2 0}$ & Variação \\
\hline Baixa magnitude & 5,2 & 3,7 & $-28,7 \%$ \\
Média magnitude & 7,7 & 6,3 & $-18,3 \%$ \\
Alta magnitude & 12,5 & 11,8 & $-6,0 \%$
\end{tabular}

Fonte: Elaboração própria com base em dados do Tribunal Superior Eleitoral, 2020.

\footnotetext{
${ }^{11}$ Foi usado o número de assentos conquistados por cada partido nas Câmaras de Vereadores para o cálculo do número efetivo de partidos de Laakso e Taagepera.
} 
É possível que os parlamentares ao votar a PEC que extinguiu as coligações nas eleições proporcionais esperassem uma redução maior na fragmentação partidária que aquelas observadas na tabela acima, principalmente para os maiores distritos que são aqueles com eleições que se assemelham mais às estudais e federais. Cabe destacar em relação a esse resultado o estudo de Borges, Silva e Ferreira (2020). A partir das novas regras eleitorais implementadas pela reforma política de 2017, os autores realizaram simulações com os dados das eleições municipais de 2016 ocorridas em São Paulo e Belo Horizonte. Eles chegaram à conclusão que o fim das coligações não causaria significativo impacto sobre a redução do número de partidos nas Câmaras Municipais. Apesar de se observar uma redução significativa do número efetivo de partidos nos pequenos distritos, para os grandes centros realmente o efeito foi compatível com a conclusão dos autores.

Porém, em relação a esse resultado é importante considerar dois fatores, o primeiro é que a mudança nas regras da distribuição das sobras eleitorais, sem grande diminuição no número de partidos nas eleições dos maiores municípios, pode ter contrabalanceado o efeito do fim das coligações. Outro aspecto é que talvez para um resultado mais conclusivo sobre as consequências das mudanças implementadas sejam necessárias eleições sucessivas com aplicação dessa regra para que ocorra uma consolidação nas estratégias eleitorais dos partidos e consequentemente também nos resultados.

\subsection{Efeito do fim das coligações nas estratégias eleitorais dos partidos em 2020}

Outro foco de análise das consequências com o fim das coligações nas eleições proporcionais é de como isso impactou nas estratégias dos partidos. Porém, antes de olhar os resultados para as eleições de 2020, seria interessante conhecer a realidade das eleições de 2016. A tabela a seguir mostra os números de municípios em que cada partido lançou candidatos a vereador e em quantos obteve sucesso.

Tabela 6 - Número de municípios que cada partido concorreu a vagas de vereador em 2016

\begin{tabular}{cccc}
\hline Municípios com & $\begin{array}{c}\text { Municípios com candidatos } \\
\text { candidatos }\end{array}$ & $\begin{array}{c}\text { Percentual de } \\
\text { aproveitamento }\end{array}$ \\
\hline PMDB & 5.067 & 3.734 & $73,7 \%$ \\
PSDB & 4.610 & 3.091 & $67,0 \%$ \\
PSD & 4.227 & 2.778 & $65,7 \%$ \\
PT & 4.200 & 1.899 & $45,2 \%$ \\
PP & 4.194 & 2.719 & $64,8 \%$ \\
PSB & 3.996 & 2.291 & $57,3 \%$ \\
PDT & 3.879 & 2.296 & $59,2 \%$ \\
DEM & 3.633 & 1.921 & $52,9 \%$
\end{tabular}




\begin{tabular}{|c|c|c|c|}
\hline $\mathbf{P R}$ & 3.604 & 2.012 & $55,8 \%$ \\
\hline PTB & 3.546 & 2.002 & $56,5 \%$ \\
\hline PRB & 3.020 & 1.229 & $40,7 \%$ \\
\hline PPS & 2.859 & 1.240 & $43,4 \%$ \\
\hline PSC & 2.756 & 1.159 & $42,1 \%$ \\
\hline PV & 2.564 & 1.094 & $42,7 \%$ \\
\hline SD & 2.491 & 1.110 & $44,6 \%$ \\
\hline PC do B & 2.245 & 743 & $33,1 \%$ \\
\hline PROS & 2.084 & 798 & $38,3 \%$ \\
\hline PHS & 1.968 & 685 & $34,8 \%$ \\
\hline PSL & 1.865 & 676 & $36,2 \%$ \\
\hline PTN & 1.723 & 612 & $35,5 \%$ \\
\hline PEN & 1.706 & 423 & $24,8 \%$ \\
\hline PRP & 1.453 & 467 & $32,1 \%$ \\
\hline PTC & 1.450 & 451 & $31,1 \%$ \\
\hline PT do B & 1.303 & 395 & $30,3 \%$ \\
\hline PMN & 1.238 & 415 & $33,5 \%$ \\
\hline PSDC & 1.191 & 329 & $27,6 \%$ \\
\hline PRTB & 1.142 & 321 & $28,1 \%$ \\
\hline PMB & 921 & 187 & $20,3 \%$ \\
\hline REDE & 712 & 158 & $22,2 \%$ \\
\hline PSOL & 584 & 34 & $5,8 \%$ \\
\hline PPL & 572 & 93 & $16,3 \%$ \\
\hline PSTU & 71 & 0 & $0,0 \%$ \\
\hline PCB & 46 & 1 & $2,2 \%$ \\
\hline PCO & 15 & 0 & $0,0 \%$ \\
\hline NOVO & 5 & 4 & $80,0 \%$ \\
\hline
\end{tabular}

Fonte: Elaboração própria com base em dados do Tribunal Superior Eleitoral, 2020.

É importante para a análise incluir também dados sobre o comportamento coligacionista dos partidos. A tabela seguinte apresenta a quantidade de municípios em que cada partido aderiu a coligações nas eleições para vereador. 
Tabela 7 - Número de municípios que cada partido concorreu a vagas de vereador em 2016 coligados e sem coligações

\begin{tabular}{|c|c|c|c|}
\hline & Coligados & Sem Coligação & Percentual sem coligação \\
\hline PMDB & 4.644 & 423 & $8,3 \%$ \\
\hline PSDB & 4.325 & 285 & $6,2 \%$ \\
\hline PSD & 4.055 & 172 & $4,1 \%$ \\
\hline PT & 3.836 & 364 & $8,7 \%$ \\
\hline $\mathbf{P P}$ & 3.970 & 224 & $5,3 \%$ \\
\hline PSB & 3.804 & 192 & $4,8 \%$ \\
\hline PDT & 3.666 & 213 & $5,5 \%$ \\
\hline DEM & 3.461 & 172 & $4,7 \%$ \\
\hline PR & 3.436 & 168 & $4,7 \%$ \\
\hline PTB & 3.386 & 160 & $4,5 \%$ \\
\hline PRB & 2.875 & 145 & $4,8 \%$ \\
\hline PPS & 2.715 & 144 & $5,0 \%$ \\
\hline PSC & 2.600 & 156 & $5,7 \%$ \\
\hline PV & 2.393 & 171 & $6,7 \%$ \\
\hline SD & 2.356 & 135 & $5,4 \%$ \\
\hline PC do B & 2.157 & 88 & $3,9 \%$ \\
\hline PROS & 1.999 & 85 & $4,1 \%$ \\
\hline PHS & 1.848 & 120 & $6,1 \%$ \\
\hline PSL & 1.783 & 82 & $4,4 \%$ \\
\hline PTN & 1.641 & 82 & $4,8 \%$ \\
\hline PEN & 1.594 & 112 & $6,6 \%$ \\
\hline PRP & 1.364 & 89 & $6,1 \%$ \\
\hline PTC & 1.375 & 75 & $5,2 \%$ \\
\hline PT do B & 1.231 & 72 & $5,5 \%$ \\
\hline PMN & 1.146 & 92 & $7,4 \%$ \\
\hline PSDC & 1.099 & 92 & $7,7 \%$ \\
\hline PRTB & 1.066 & 76 & $6,7 \%$ \\
\hline PMB & 861 & 60 & $6,5 \%$ \\
\hline REDE & 622 & 90 & $12,6 \%$ \\
\hline PSOL & 202 & 382 & $65,4 \%$ \\
\hline PPL & 502 & 70 & $12,2 \%$ \\
\hline PSTU & 15 & 56 & $78,9 \%$ \\
\hline PCB & 25 & 21 & $45,7 \%$ \\
\hline PCO & - & 15 & $100,0 \%$ \\
\hline NOVO & - & 5 & $100,0 \%$ \\
\hline
\end{tabular}

Fonte: Elaboração própria com base em dados do Tribunal Superior Eleitoral, 2020.

Cabe nesse ponto lembrar a teoria de Soares (1964) sobre o comportamento coligacionista 
dos partidos. A racionalidade da resistência ideológica fica muito clara na tabela acima quando são analisados os números para os partidos mais ideológicos, aqueles que estão destacados em cinza. Particularmente, os partidos com ideologia mais enraizada como PCO e NOVO não realizaram nenhuma aliança nas eleições de 2016. Porém, ao contrário do que Soares (1964) apresentou em seu trabalho, os partidos que mais se coligaram nessas eleições municipais foram os grandes e médios. Mas será que a realização de coligações estava associada a resultados melhores para esses partidos? O próximo gráfico traz uma amostra de como concorrer participando de coligações afetou o desempenho dos partidos nas eleições de 2016.

Gráfico 3 - Índice de Sucesso dos Partidos ${ }^{12}$ para eleição de vereador em 2016 com e sem coligações

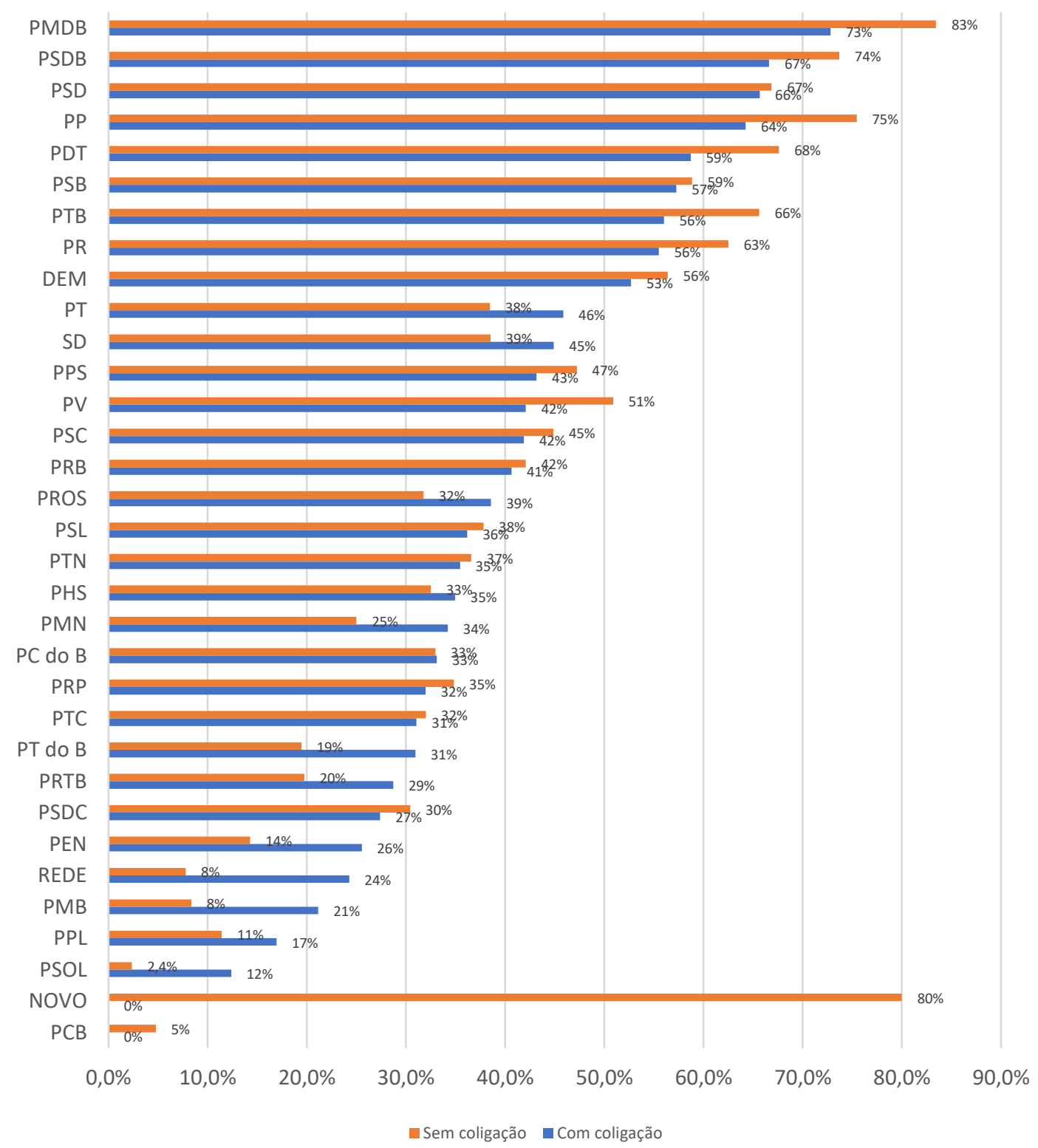

Fonte: Elaboração própria com base em dados do Tribunal Superior Eleitoral, 2020.

12 O Índice de Sucesso dos Partidos é obtido através da razão o número de municípios com vereadores eleitos pelo partido pelo número total de municípios com candidatos a vereador 
Observa-se que já em 2016 a maioria dos partidos obteve resultados melhores quando concorreu sozinho do que aliado a outra legenda. É interessante destacar que dos 15 maiores partidos só dois tiveram desempenhos piores quando concorreram de forma independente - PT e Solidariedade -, no entanto, entre os 15 menores partidos, 10 tiveram desempenho melhor nas coligações. Cabe aqui resgatar passagem da justificativa do Projeto de Lei 2679/2003 apresentado pela Comissão Especial da Câmara dos Deputados Destinada a Efetuar Estudo em Relação à Reforma Política em 2003:

\begin{abstract}
A mecânica mencionada é habitualmente ignorada pelo eleitor, que sufraga um candidato, sem saber que o voto que a ele confere pode, na verdade, vir a eleger candidato de outro partido. Não raro, um candidato da agremiação maior na coligação deixa de ser eleito, porque vem a ser preterido pelo da agremiação menor. Esta, sem a coligação, não teria alcançado o quociente.
\end{abstract}

Esse trecho destaca exatamente o efeito que as coligações parecem ter tido nos resultados eleitorais de 2016, e que gerava reclamações recorrentes dos parlamentares dos maiores partidos.

Essa visão geral dos resultados de 2016 auxilia na análise da influência que o fim das coligações nas eleições proporcionais teve nas estratégias dos partidos em 2020. Vários partidos médios e pequenos têm diretórios apenas nos maiores centros urbanos e verifica-se nos dados que, possivelmente com intuito de concentrar forças, eles reduziram o número de municípios com candidatos para vereador. Albuquerque (2017) já salientava em seu estudo que a capilaridade dos partidos no território brasileiro poderia ter esse tipo de influência nos resultados.

Tabela 8 - Número de municípios que cada partido concorreu a vagas de vereador em 2016 e 2020

\begin{tabular}{ccc}
\hline PMDB & $\mathbf{2 0 1 6}$ & $\mathbf{2 0 2 0}^{\mathbf{1 3}}$ \\
PSDB & 5.067 & 3.236 \\
PSD & 4.610 & 2.375 \\
PT & 4.227 & 2.764 \\
PP & 4.200 & 2.813 \\
PSB & 4.194 & 2.778 \\
PDT & 3.996 & 1.944 \\
DEM & 3.879 & 2.066 \\
PR/PL & 3.633 & 2.322 \\
PTB & 3.604 & 2.018 \\
PRB/REPUBLICANOS & 3.546 & 1.734 \\
PPS/CIDADANIA & 3.020 & 1.925 \\
PSC & 2.859 & 1.206 \\
\hline
\end{tabular}

\footnotetext{
${ }^{13} \mathrm{Na}$ data de extração dos dados, 10 de dezembro de 2020, apenas 5226 municípios estavam com dados completos disponíveis no repositório de dados eleitorais do TSE.
} 


\begin{tabular}{ccc} 
PV & 2.564 & 856 \\
SOLIDARIEDADE & 2.491 & 1.155 \\
PC do B & 2.245 & 777 \\
PROS & 2.084 & 792 \\
PHS & 1.968 & Fundiu-se ao Podemos \\
PSL & 1.865 & 1.555 \\
PTN/PODEMOS & 1.723 & 1.402 \\
PEN/PATRIOTA & 1.706 & 960 \\
PRP & 1.453 & Fundiu-se ao Patriota \\
PTC & 1.450 & 421 \\
PT do B/AVANTE & 1.303 & 981 \\
PMN & 1.238 & 318 \\
PSDC & 1.191 & 311 \\
PRTB & 1.142 & 534 \\
PMB & 921 & 166 \\
REDE & 712 & 339 \\
PSOL & 584 & 530 \\
PPL & 572 & 45 \\
PSTU & 71 & 24 \\
PCB & 46 & 23 \\
PCO & 15 & 46 \\
NOVO & 5 & Fundiu-se ao PC do B \\
\hline
\end{tabular}

Fonte: Elaboração própria com base em dados do Tribunal Superior Eleitoral, 2020.

Como é possível observar na tabela, com exceção dos partidos NOVO e PCO, todos os demais reduziram o número de municípios em que lançaram candidatos a vereador. Apesar dessa redução, os dados revelam também que o percentual de sucesso dos partidos aumentou consistentemente. 
Gráfico 4 - Índice de Sucesso dos Partidos nas eleições para vereador em 2016 e 2020

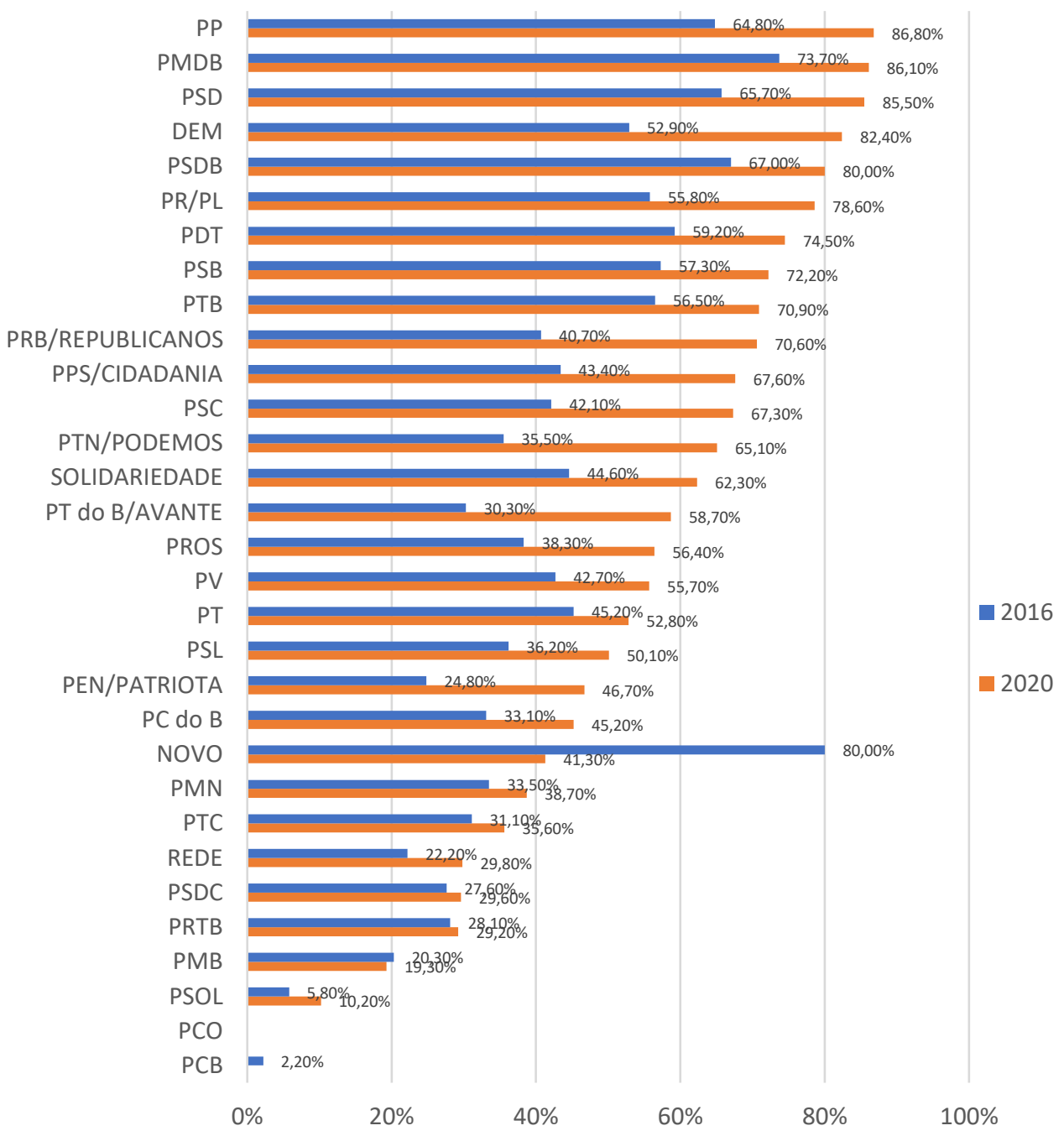

Fonte: Elaboração própria com base em dados do Tribunal Superior Eleitoral, 2020.

Apenas o partido NOVO e PMB tiveram índices inferiores aos obtidos em 2016. O primeiro teve uma queda explicada pelo fato de que em 2016 o partido recém-criado lançou candidatos a vereador em apenas cinco municípios e, em 2020, foram mais de 45 municípios com candidatos do partido. Então naturalmente haveria uma redução no seu índice de sucesso.

O resultado do segundo está ligado à perda de força política no decorrer desse período entre as eleições. Esses dados parecem transmitir a ideia de que, sem a possibilidade de realizar coligações, a estratégia geral dos partidos realmente foi alterada e a concentração de esforços em municípios com maior chance de conquistar vagas teve sucesso.

\subsection{Distorções provocadas pelo fim das coligações}

Como já era esperado e foi até apontado por estudiosos como Silva (2015) aconteceram algumas distorções eleitorais com o fim das coligações. Apesar da nova regra para distribuição das sobras eleitorais ter remediado parcialmente a situação, um dos fenômenos observados nas 
eleições de 2020 foi o monopólio de partidos em alguns municípios. Enquanto em 2016 isso aconteceu apenas em um município, Nova América da Colina - PA, em 2020 ao menos ${ }^{14} 14$ municípios elegeram vereadores de apenas um partido, gerando uma Câmara de Vereadores unipartidária, sendo 13 no Nordeste. A tabela seguinte traz a relação de municípios em que ocorreu tal fenômeno:

Tabela 9 - Relação de municípios com monopólio de partidos nas câmaras municipais

\begin{tabular}{ccc}
\hline UF & Município & $\begin{array}{c}\text { Partido dos } \\
\text { Vereadores }\end{array}$ \\
\hline MA & São Pedro dos Crentes & PSL \\
PI & Curral Novo do Piauí & MDB \\
PI & Belém do Piauí & MDB \\
RN & Frutuoso Gomes & MDB \\
RN & Viçosa & Republicanos \\
PB & Bom Sucesso & DEM \\
PB & Vista Serrana & MDB \\
PB & Monte Horebe & MDB \\
PB & Ouro Velho & DEM \\
PB & São José do Sabugi & DEM \\
AL & Cacimbinhas & MDB \\
SE & São Miguel do Aleixo & PSC \\
PE & Quixabá & Avante \\
RS & Barra do Rio Azul & PSD \\
\hline
\end{tabular}

Fonte: Elaboração própria com base em dados do Tribunal Superior Eleitoral, 2020.

É interessante destacar que apenas em São Miguel do Aleixo e em Barra do Rio Azul os prefeitos eleitos eram de partidos diferentes dos vereadores, PSD e PTB respectivamente, apesar de serem da mesma coligação na eleição majoritária. Em termos de funcionamento das instituições, essa situação pode criar uma distorção nas relações entre os poderes Executivo e Legislativo. Afinal, além de legislar, é papel dos vereadores fiscalizar a atuação do prefeito. Além desse aumento de monopólios partidários nas câmaras municipais, aconteceu um fenômeno inusitado e não verificado em 2016. Houve nas eleições de 2020 dois municípios em que só concorreram candidatos de um único partido, o MDB em Frutuoso Gomes e o PSD em Barra do Rio Azul.

O número de municípios que elegeram vereadores de apenas dois partidos também teve um grande crescimento, de 33 em 2016 para mais de 490 em 2020, sendo entre eles 6 de média magnitude. Ampliando essa análise para as Câmaras de Vereadores que terão no máximo 4

\footnotetext{
${ }^{14}$ Utilizou-se o termo "ao menos" porque no momento que o trabalho foi escrito não estavam disponíveis para análise dados completos de $100 \%$ dos municípios.
} 
partidos com representação, os dados mostram um aumento ainda mais expressivo: de 14,1\% em 2016 para 47,2\% em 2020. Como essas mudanças em sua grande maioria ocorreram nos menores municípios, fica o questionamento se a forma que foi implementada o fim das coligações poderia ser responsável por um efeito redutor do pluripartidarismo no interior do país no médio ou longo prazo.

Outro fenômeno não esperado que os dados demostraram foi um aumento do número efetivo de partidos nas câmaras municipais de mais de $40 \%$ dos municípios classificados como de alta magnitude. Entre eles, Rio de Janeiro, Curitiba, Manaus, Fortaleza, Salvador, São Paulo e Porto Alegre. Destaque para esses dois últimos que tiveram aumento de $12 \%$ e 17\%, respectivamente. Esse resultado, apesar de ser uma distorção quando se considera a expectativa que tinham os parlamentares que implementaram as mudanças eleitorais, não era totalmente inesperado. Conforme mencionado anteriormente, Borges, Silva e Ferreira (2020) em seu estudo já haviam chegado à conclusão de que o fim das coligações poderia não causar significativo impacto sobre a redução do número de partidos nas câmaras municipais. No entanto, agora com todos dados das eleições de 2020 disponíveis, esse resultado merece ser analisado com mais cuidado em estudos futuros, principalmente considerando que esses municípios são exatamente aqueles que apresentam dinâmica eleitoral mais próxima da que se espera para as eleições 2022.

Por fim, nenhuma dessas inconsistências apresentadas neste trabalho tem como finalidade questionar a validade do fim das coligações nas eleições proporcionais. O objetivo é simplesmente apontar esses efeitos que aconteceram nas eleições municipais de 2020 e não eram esperados com

a adoção da medida. É muito importante salientar que para concluir se esses efeitos foram ocasionais ou serão recorrentes, talvez seja necessário um maior tempo de observação da implementação das novas regras com a realização de sucessivas eleições.

\section{Conclusões}

A ideia desse trabalho é ser um estudo exploratório e preliminar sobre as consequências que o fim das coligações nas eleições proporcionais pode ter causado nos resultados nos pleitos municipais de 2020. Exploratório por utilizar uma base de dados do Tribunal Superior Eleitoral que ainda está sofrendo constantes alterações ou revisões e também pelas análises serem de natureza mais qualitativa, não utilizando nenhuma técnica de inferência estatística. Preliminar porque pretende-se atualizar as tabelas e gráficos aqui apresentados quando os dados do TSE estiverem consolidados para todos os municípios. Apesar dessas restrições, as informações apresentadas são úteis para fornecer um panorama de como o fim das coligações pode ter alterado a dinâmica das eleições municipais, principalmente no que se refere às estratégias dos partidos. $\mathrm{O}$ estudo obteve resultados interessantes sobre como as coligações possivelmente se relacionam com a fragmentação partidária, porém mostrou que sua influência é afetada, por exemplo, pelo tamanho do distrito. Aprofundamentos sobre como essa dinâmica acontece regionalmente ou a 
influência de características demográficas dos municípios seriam importantes para definição de um quadro mais completo e ficam como sugestões para estudos futuros.

Cabe destacar que tanto os trabalhos revisados quanto os debates dos parlamentares durante a tramitação da proposta não discutiam de forma intensa sobre uma redução tão significativa no número de partidos que participariam das eleições, como foi observado nos dados. O foco maior geralmente era no efeito redutor do número de partidos que obteriam sucesso eleitoral com as novas regras implementadas (ALBUQUERQUE, 2017). No entanto, como pôde ser percebido nos dados, a primeira redução foi bem mais significativa. Esse também se mostra ótimo campo para futuras pesquisas, pois cabe aqui uma análise mais detalhada sobre como se deu o comportamento dos partidos e quais efeitos isso pode ter na nacionalização das grandes legendas e concentração das pequenas nas maiores cidades. Deve-se lembrar de que com a implementação de cláusulas de desempenho mais rígidas, que acontecerão nas próximas eleições, e consequentemente a extinção ou fusão de algumas siglas, esse fenômeno deve se agravar em 2024.

Em relação às possíveis consequências para as eleições federais e estaduais de 2022, seria interessante realizar um estudo focado nos resultados das grandes cidades para o pleito municipal de 2020. Sabe-se que as eleições nos distritos de alta magnitude são as que mais se assemelham em perfil às eleições federais e estaduais devido ao número de candidatos e às estratégias eleitorais adotadas pelos partidos. Dessa forma, foi observada uma menor redução da fragmentação partidária nas Câmaras Municipais dessas cidades, como previamente apontada por Borges, Silva e Ferreira (2020) e observada pelo cálculo do número efetivo de partidos em 2020. É possível que devido à maior proporcionalidade que a fórmula eleitoral brasileira produz nos maiores distritos, uma redução mais significativa da fragmentação partidária nesses locais necessite da implementação de regras específicas para eles. Porém, para qualquer conclusão mais consistente, esse fenômeno deveria ser analisado de forma mais detalhada permitindo uma melhor compreensão, de preferência observando-se novas eleições com aplicação da mesma regra.

Sobre as estratégias partidárias adotadas pelos partidos, verificou-se que elas parecem ter funcionado, resultando em um aumento no Índice de Sucesso dos Partidos, principalmente para os maiores. Pesquisas futuras podem analisar se a diminuição do número de partidos nesses municípios foi acompanhada de uma redução no número de candidatos ou se simplesmente o que aconteceu foi uma migração local de candidatos para os maiores partidos. Os resultados mostram ainda que ideias apresentadas durante as discussões pelos parlamentares sobre as coligações prejudicarem os resultados eleitorais dos partidos médios e grandes estavam parcialmente corretas (BRASIL, 1999). Esses partidos efetivamente alcançaram resultados melhores nos municípios em que concorreram nas eleições municipais. No entanto, a impossibilidade de realizar alianças teve como consequência participação em uma quantidade menor de pleitos municipais. Logo o Índice de Sucesso Partidário aumentou, mas o número absoluto de municípios com representação nas 
câmaras de vereadores foi menor para quase todos os partidos. Isso vai ao encontro do pensamento de Braga (2006) que acreditava que o recurso das coligações era essencial para as estratégias de sobrevivência dos partidos em cada um dos níveis de disputa da federação e consequentemente para um maior grau de nacionalização dos partidos.

Em relação às distorções observadas, como o monopólio de partidos em alguns municípios, elas dificilmente serão observadas nas eleições estaduais e federais devido ao número de partidos que participa desses pleitos - mesmo nos estados de baixa magnitude como Acre, Roraima e Distrito Federal. Porém, fica o questionamento se o fim das coligações que aparentemente reduziu o número de partidos com candidatos nos pequenos municípios, no médio prazo, pode ser responsável ao longo do tempo por um efeito redutor do pluripartidarismo no interior do país. Outro ponto observado, particularmente para os municípios em que houve monopólio de partidos, foi a relação entre as coligações dos prefeitos eleitos e as legendas que elegeram vereadores. Sobre esse aspecto seriam interessantes dois estudos: um que acompanhasse o funcionamento da política local desses municípios em que não haverá oposição formal; e outro mais aprofundado analisando como as eleições majoritárias influenciaram na participação dos partidos que concorreram a vagas nas câmaras municipais. Merece atenção também o aumento no número efetivo de partidos nas câmaras municipais de mais de $40 \%$ dos municípios de alta magnitude.

Enfim, a intenção é que esse estudo auxilie pesquisas futuras daqueles que procuram entender as consequências que esse fenômeno pode trazer para o sistema político brasileiro e também abra portas para novos questionamentos. Com certeza o debate sobre esse tema continuará intenso na literatura da ciência política até as eleições de 2022, e muito provavelmente se estenderá por bastante tempo depois disso.

\section{REFERÊNCIAS}

ALBUQUERQUE, Felipe de. Uma análise das coligações proporcionais de 2010 e 2014.

Revista Eletrônica de Ciência Política. v. 8, n. 2, 2017. Disponível em https://www.researchgate.net/publication/321175418_Uma_analise_das_coligacoes_propor cionais_de_2010_e_2014. Acesso em 10 de dez. 2020.

BORGES, Gabriel Augusto Mendes; SILVA, Adriana Campos; FERREIRA, Raphael Rodrigues. Fim das Coligações para Vereadores... E agora? Brasília: Núcleo de Estudos e Pesquisas/CONLEG/Senado. Set. 2020 (Texto para Discussão n. 285). Disponível em https://www.senado.leg.br/estudos. Acesso em 10 de dez. 2020.

BRAGA, Maria do Socorro. Dinâmica de Coordenação Eleitoral em Regime Presidencialista e Federativo: Determinantes e Consequiências das Coligações Partidárias no Brasil. In: SOARES, Gláucio Ary; RENNÓ, Lúcio (orgs.), Reforma Política. Lições da História Recente. Rio de Janeiro: Editora FGV, 2006, p. 229-245.

BRASIL. Câmara dos Deputados. Projeto de Lei n. 2.679 de 3 de dezembro de 2003. Dispõe sobre as pesquisas eleitorais, o voto de legenda em listas partidárias preordenadas, a instituição de federações partidárias, o funcionamento parlamentar, a propaganda eleitoral, o financiamento 
de campanha e as coligações partidárias, alterando a Lei $\mathrm{n}^{\circ}$ 4.737, de 15 de julho de 1965 (Código Eleitoral), a Lei n ${ }^{\circ}$ 9.096, de 19 de setembro de 1995 (Lei dos Partidos Políticos) e a Lei n ${ }^{\circ}$ 9.504, de 30 de setembro de 1997 (Lei das Eleições). Disponível em: https://www.camara.leg.br/proposicoesWeb/fichadetramitacao?idProposicao=147024. Acesso em 10 dez. 2020.

BRASIL. Câmara dos Deputados. Proposta de Emenda à Constituição n. 282/2016. Parecer na CCJC. Deputado Betinho Gomes. Brasília, 4 abr. 2017. Parecer do Relator, Dep. Betinho Gomes (PSDB-PE), pela admissibilidade desta, da PEC 22/2015 e da PEC 84/2011, apensadas. Disponível em:

https://www.camara.leg.br/proposicoesWeb/fichadetramitacao?idProposicao=2128031. Acesso em 10 de dez. 2010.

BRASIL. Câmara dos Deputados. Proposta de Emenda à Constituição n. 282/2016. Parecer na Comissão Especial - PEC 282/16. Deputada Shéridan. Brasília, 22 ago. 2017. Parecer da Relatora, Dep. Shéridan (PSDB-RR), pela admissibilidade das emendas parlamentares números 1 a 12 e, no mérito, pela APROVAÇÃO da PEC nº 282/2016 e das emendas de número 3, 4, 7 , 8 e 11 nos termos do substitutivo apresentado por esta Relatoria, e pela rejeição da PEC $n^{\circ}$ 84/2011, da PEC n 22/2015 e das emendas 1, 2, 5, 6, 9, 10 e 12. Brasília: Câmara dos Deputados, 2017. Disponível em:

https://www.camara.leg.br/proposicoesWeb/fichadetramitacao?idProposicao=2148606. Acesso em 10 de dez. 2010.

BRASIL. Câmara dos Deputados. Projeto de Lei n. 669/1999. Altera o art. $6^{\circ}$ da Lei no 9.504 , de 30 de setembro de 1997, impedindo a celebração de coligações para eleição proporcional. Disponível em: https://www.camara.leg.br/propostas-legislativas/15716. Acesso em $10 \mathrm{de} \mathrm{dez.}$ 2020.

BRASIL. Decreto $\mathbf{n}^{\circ}$ 21.076, de 24 de fevereiro de 1932 (Código Eleitoral). Regula em todo o país o alistamento eleitoral e as eleições federais, estaduais e municipais. Rio de Janeiro, RJ: Presidência da República, 1932. Disponível em https://legis.senado.leg.br/norma/440250/publicacao/15695060. Acesso em 10 de dez. 2020.

BRASIL. Emenda Constitucional n. 97, de 4 de outubro de 2017. Altera a Constituição Federal para vedar as coligações partidárias nas eleições proporcionais, estabelecer normas sobre acesso dos partidos políticos aos recursos do fundo partidário e ao tempo de propaganda gratuito no rádio e na televisão e dispor sobre regras de transição. Disponível em: http://www.planalto.gov.br/ccivil_03/constituicao/emendas/emc/emc97.htm Acesso em $10 \mathrm{de}$ dez. 2020.

BRASIL. Lei n. 13.488 de 06 de outubro de 2017. Altera as Leis $n^{\circ} 9.504$, de 30 de setembro de 1997 (Lei das Eleições), 9.096, de 19 de setembro de 1995, e 4.737, de 15 de julho de 1965 (Código Eleitoral), e revoga dispositivos da Lei no 13.165, de 29 de setembro de 2015 (Minirreforma Eleitoral de 2015), com o fim de promover reforma no ordenamento políticoeleitoral. Brasília, DF: Presidência da República, 2017. Disponível em: http://www.planalto.gov.br/ccivil_03/_ato2015-2018/2017/lei/L13488.htm. Acesso em $10 \mathrm{de}$ dez. 2020.

BRASIL. Tribunal Superior Eleitoral. Estatísticas Eleitorais. Disponível em: https://www.tse.jus.br/eleicoes/estatisticas/repositorio-de-dados-eleitorais-1/repositorio-dedados-eleitorais. Acesso em 10 de dez. 2020.

BRASIL. Tribunal Superior Eleitoral. Estatísticas Eleitorais. Repositório de Dado Eleitorais: Eleições Municipais 2020. Disponível em:

https://www.tse.jus.br/eleicoes/estatisticas/estatisticas-eleitorais. Acesso em 10 de dez. 2020.

CARREIRAO, Yan de Souza. Ideologia e partidos políticos: um estudo sobre coligações em Santa Catarina. Opinião Pública, Campinas, v. 12, n. 1, p. 136-163, abr. 2006. Disponível em http://dx.doi.org/10.1590/S0104-62762006000100006. Acesso em 10 de dez. 2020. 
DALMORO, Jefferson; FLEISCHER, David. Eleição proporcional: os efeitos das coligações e o problema da proporcionalidade. In: KRAUSE, Silvana; SCHMITT, Rogério (Org.), Partidos e coligações eleitorais no Brasil. Rio de Janeiro: Konrad Adenauer Stiftung / São Paulo: Ed. UNESP, 2005, p. 85-113.

LAAKSO, M.; TAAGEPERA, R. "Effective" Number of Parties: A Measure with Application to West Europe. Comparative Political Studies, v. 12, n. 1, p. 3-27, Apr. 1979. Disponível em: https://doi.org/10.1177/001041407901200101. Acesso em 10 dez. 2020.

MELO, Clóvia A. Vieira de; SOARES, Kelly C. Costa. Coligações partidárias em eleições proporcionais municipais: fragmentação e sucesso de candidatos com baixa densidade eleitoral. Análise Social, n. 220, p. 684-719, set. 2016. Disponível em http://www.scielo.mec.pt/scielo.php?script=sci_arttext\&pid=S000325732016000300007\&lng=p t\&nrm=iso. Acesso em $10 \mathrm{dez} .2020$.

MIRANDA, Geralda Luiza. Coligações Eleitorais: Tendências e Racionalidades nas Eleições Federais e Majoritárias Estaduais (1990-2010). Revista de Sociologia Política v. 21, n. 47, p 69-90, set. 2013. Disponível em: https://www.scielo.br/pdf/rsocp/v21n47/07.pdf. Acesso em 10 de dez. 2020.

NICOLAU, Jairo Marconi. Breves comentários sobre as eleições de 1994 e o quadro partidário. Cadernos de Conjuntura, Rio de Janeiro, IUPERJ, n. 50, p.15-19, julho 1994.

NICOLAU, Jairo Marconi. Multipartidarismo e democracia: um estudo sobre o sistema partidário brasileiro (1985-1994). Rio de Janeiro: Editora FGV, 1996.

NICOLAU, Jairo Marconi; SCHMITT, Rogério Augusto. Sistema eleitoral e sistema partidário. Lua Nova, São Paulo, n. 36, p. 129-147, 1995. Disponível em https://doi.org/10.1590/S0102-64451995000200008. Acesso em 10 de dez. 2020.

NOHLEN, Dieter. Os sistemas eleitorais: o contexto faz a diferença. Lisboa: Livros Horizonte, 2006.

PAIVA, Denise; ALVES, Vinícius; BENEDITO, Sergio. As coligações proporcionais e os pequenos partidos nas eleições para a Câmara de Deputados 1998-2014. In: MIGUEL, Luis Felipe; KRAUSE, Silvana; MACHADO, Carlos Augusto Mello. Coligações e Disputas Eleitorais na Nova República: Aportes teórico-metodológicos, tendências e estudos de caso. Rio de Janeiro: Fundação Konrad Adenauer/São Paulo: Editora Unesp, p. 321-364, 2017.Disponível em:https://www.researchgate.net/publication/315745579_As_coligacoes_proporcionais_e_os_p equenos_partidos_nas_eleicoes_para_a_Camara_de_Deputados_1998-2014. Acesso em $10 \mathrm{de}$ dez. 2020.

SILVA, Raphael Carvalho da. Análise dos possíveis impactos das propostas de fim das coligações proporcionais, para as eleições da Câmara dos Deputados, a partir dos resultados de 2014. Brasília, Câmara dos Deputados: Consultoria Legislativa. 2015 (Estudo, maio 2015). Disponível em https://bd.camara.leg.br/bd/handle/bdcamara/22200. Acesso em 10 de dez. 2020.

SOARES, Gláucio Dillon. Alianças e coligações eleitorais: notas para uma teoria. Revista Brasileira de Estudos Políticos, Belo Horizonte, n. 17, p. 95-112, 1964.

SOUZA, Maria do Carmo Campello de. Estado e partidos políticos no Brasil. São Paulo: Alfa-Ômega, 1976.

TAVARES, José Antônio Giusti. Reforma política e retrocesso democrático. Porto Alegre: Mercado Aberto, 1998.

Artigo submetido em: 2021-01-23; Artigo reapresentado em: 2021-03-06; Artigo aceito em: 2021-04-09 